\title{
Remittance Received by Households of Western Chitwan Valley, Nepal: Does Migrant's Destination Make a Difference?
}

\section{Prem Bhandari}

\begin{abstract}
Studies on migration in Nepal primarily focused on the causes of migration, in general. While a few studies examined the remittances received or sent by migrants, there is little information about the variation in remittances received by households by migrant's destination. Thus, this exploratory study attempts to answer: Does the extent to which households receive remittances vary by migrant's destination? Using the data collected in 2013 from the western Chitwan Valley of Nepal, the findings from multivariate analysis reveal that net of controls, both the receipt (whether a household received any remittance or not) as well as the amount of remittances received by a household varied by migrant's destination. Evidence suggests that households are less likely to receive remittances from migrants working in India (a country of low earning potential) as compared to those working in Nepal. On the other hand, households received significantly more amount of remittances from migrants working in countries with high earning potentials (such as Middle East, East or South East Asia, and America, Australia and Europe) as compared to the domestic migrants who were working inside of Nepal but outside of Chitwan. Adjusting for other factors, the largest amount of remittances was received from migrants working in the East or South East Asian countries (e.g. South Korea, Malaysia, Japan) followed by those in America, Australia, and Europe and the Middle East. The insights gained from this exploratory study are discussed.
\end{abstract}

Keywords: destination, migration, Nepal, remittance, South Asia 


\section{Introduction}

This exploratory study examines the remittances received by households from migrant members of remittance dependent households of Nepal with particular focus in the clusters of Chitwan district. Here, the remittance receipt is defined as the money, goods or gifts received by a household from domestic migrants working outside of Chitwan in Nepal or abroad.

Previous migration research in Nepal primarily focused on the causes of out-migration, in general (Bhandari, 2004, Bhandari \& Ghimire, 2016; Bohora-Mishra, 2013; Bohora-Mishra \& Massey, 2009; 2011; Gurung, 2012; Massey et al., 2010; Massey, Axinn \& Ghimire, 2010; Piotrowski, 2013; Piotrowski et al., 2013; Shrestha \& Bhandari, 2007; Williams, 2009; 2013). Kern \& Muller-Boker (2015) provide a detailed description of the process and the role of recruitment agencies on Nepali migration. Gurung (2012) examined the role social exclusion plays on destination specific out-migration of individuals in Nepal. A few studies provided valuable descriptive information on migrants and remittances (Adhikari, 2001; Central Bureau of Statistics, 2011; Hoermann \& Kollmair, 2009; Pant, 2008; Seddon, Adhikari \& Gurung, 2002; Sharma \& Gurung, 2009; Seddon, Gurung \& Adhikari 1998; Thieme \& Wyss, 2005; Williams et al., 2012).

Of particular interest to this study, Thieme and Wyss (2005) explored migration patterns and remittances transfer using data from a rural setting of western Nepal. Specifically, they revealed that there are specific ways of organizing migration for various destinations. These country specific ways of organizing migration demand specific assets from prospective migrants and their household members and, therefore, influence their choice of destination. In addition, Thieme and Wyss (2005) also provide information on organization of destination specific migration by Nepali migrants and the process of transfer of remittances back home. Williams et al. (2012) provide insights into the lives, work, values, beliefs, behaviors and intentions of Nepali migrants living in the Gulf Cooperation Council (GCC) countries. Particular to remittances, Williams et al. (2012) examine the factors contributing to the remittances transferred by migrants to their residence in Nepal. In addition, Seddon, Gurung 
and Adhikari (1998), using the 1996 Nepal Living Standard Survey data provide descriptive insights on destination specific migration and the remittances sent by migrants to Nepal. Although Williams et al. (2012) and Seddon et al. (1998) reported that the amount of remittances varied by migrant's destination, these studies do not provide information on remittances received by households. It is believed that the amount of remittances sent by migrants and the amount received by a household may vary. Because migrants may send remittances to different people living in multiple places e.g. parents, in-laws, spouse, children and others, the amount reported by a migrant and a household thus could vary. Bhandari and Chaudhary (2015) explored remittance receipt and remittance use and examined the uses of remittances in various socio-economic and cultural dimensions of household activities in a western Chitwan valley of Nepal. While these studies make important contributions to the field of migration and remittance research, yet, studies those examine destination specific remittances received by households is an important research gap in Nepal.

This study aims to fulfil the important gap in migration and remittance literature by investigating two important research questions: Whether or not a household's receipt of remittances does vary by migrant's destination? If it does vary, does the extent to which the amount of remittances is received vary by destinations? This study affords to answer the questions by using the remittance receipt data collected in 2013 from the western Chitwan Valley - a remittance dependent setting of rural Nepal. This exploratory study collected information on migrant destinations, the amount of remittances received from each migrant and migrants' characteristics.

\section{Migration and Remittances in Nepal}

Nepal has a long history of migration. Nepal was once the melting pot of Indo-Aryan ancestry origin migrants from the South and Mongolian origin Tibeto-Burmese from the North. The country experienced a rapid growth in internal migration during 1950s when the Nepali government opened the Tarai region (southern plain) for settlement by clearing the dense forest. This Gangetic plain also termed as 'the granary of the country' is highly fertile and suitable for agriculture. Since then the internal migration tremendously 


\section{4| Prem Bhandari}

increased especially from the hills and mountains (Gurung, 1998). Now, the country has turned into one of the major migrant sending areas.

In Nepal, international labor migration formally began in 1815 AD with the recruitment of Nepali youth in The British Brigade of Gurkha - units of the British Army that were composed of Nepalese soldiers (Gurung, 1983; Rathaur, 2001; Thieme, Susan \& Wyss, 2005). However, this was not a viable option until recently. In 1989, the Nepali government promulgated the Foreign Employment Act to destinations other than India. This Act licensed non-governmental institutions to export Nepali workers abroad and legitimized certain labor contracting organizations. This exploded large streams of international migration outside of India (Kollmair et al., 2006; Thieme \& Wyss, 2005).

Recent estimates suggest that there may be as many as three million Nepalis, or about 10 percent of the total population, working abroad (Government of Nepal, 2071 (2014); World Bank, 2009). The percentage of migrants is much higher for young people and for men. In 1997, about 100,000 migrants were estimated working outside of Nepal (excluding India) (Seddon, Adhikari, \& Gurung, 2002). The 2011 population census reported about 2 million individuals as migrants (Central Bureau of Statistics, 2012). More recently, migration has been a rite of passage and a matter of social status and prestige for individuals (Thieme \& Wyss, 2005). Over 1500 Nepalis move outside of the country everyday (Kern \& Muller-Boker, 2015; Pattison, 2014). Undocumented migration is also very high and it is difficult to estimate precisely the number of Nepalis who have migrated outside the country.

With the increased volume of out-migration, the volume of remittances is also increasing over time in Nepal. Estimates show that the remittances from out-migration accounted for about 29 percent of GDP (World Bank, 2016). This account does not capture the remittances received through informal channels. Now, Nepal stands as the third largest remittance recipient in its contribution to GDP in the world, whose position was sixth in 2011 (World Bank, 2011; 2016). 
Remittances have become an important source of household income for Nepalis (Adhikari, 2001; Hoermann \& Kollmair, 2009; Pant, 2008; Sharma \& Gurung, 2009). The Nepal Living Standard Survey $(2010 / 11)$ reports that 56 percent of the households in Nepal receive remittances (Central Bureau of Statistics, 2011). On average, the income transfer in the form of remittances is Rs 80,436 (in nominal terms) per year per recipient household. The most recent Household Budget Survey revealed that in 2014/15 remittance was the third (17.61\%) most important source of a household's monthly income after salary, wages, allowance and pension (30.26\%) and business income (24.43\%) (Nepal Rastra Bank, 2016). In rural Nepal, it was the second most important source of household income.

\section{Migrant Destinations and Destination Specific Earning Potentials}

Nepali migrants are distributed worldwide. In 1997, excluding India, they were reported in 25 countries (Seddon, Adhikari \& Gurung, 2002). Recent data for 2013/14 shows that Nepalis are working in 131 countries (Government of Nepal, 2014).

Until 1990s, India was the most popular international destination for Nepali workers. Migration to India still dominates due to its open border, socio-cultural and linguistic similarities, and past migration experiences. The 2009 Nepal Migration Survey estimates that of the total 2.1 million Nepali work migrants, 41 percent were in India, 38 percent in the Middle Eastern Gulf countries, 12 percent in Malaysia and 8.7 percent in other developed countries (World Bank, 2011). However, more recently, countries in the Middle East, South East Asia, the West (Northern Europe and North America) and Australia have been the popular destinations. In 2009, excluding India, Malaysia, Saudi Arab, Qatar, and United Arab Emirates accounted for nearly 85 percent of international migrants (Ozaki, 2012). About 75 percent Nepali international migrants are unskilled and are employed mainly in entry-level jobs such as cleaning and construction (Kern \& Muller-Boker, 2015).

Earning potentials of migrants vary by destinations. Destination such as India is easily accessible to migrants compared to other international destinations, but earning potentials in India are 


\section{6| Prem Bhandari}

relatively less. Seddon, Gurung \& Adhikari (1998) reported that migration to the Middle Eastern countries have relatively better earnings compared to India but less earnings compared to other destinations such as America, Australia, the United Kingdom, Japan, Malaysia, South Korea, and Thailand. Thus countries of Europe and North America, and East and South East Asia are generally desired by Nepali migrants for higher wages, better working conditions and possibilities for accumulation. Japan is the most favored destination for Nepalis with high wages and large savings for a successful migrant (Thieme and Wyss, 2005). Seddon et al. (1998) further revealed that even the lowest level of monthly remittances from the West, and from the Far East and South East Asia are significantly higher than the average sent back from the Gulf or India (Seddon et al., 1998; Thieme and Wyss, 2005). Moreover, Seddon et al. (1998) and Williams et al. (2012) reported that there is variation in the amount of remittances sent by a migrant. Despite these, whether the receipt of remittances or the extent to which the amount received by a household does vary by migration destinations adjusting for other factors is not clear.

\section{Hypothesis on Destination Specific Remittances Received by Households}

Given the background above, this study investigates the remittance receipt by migrant households using the New Economics of Labor Migration (NELM) framework. According to NELM, migration of individuals is a family-based decision and is an attempt to diversify household income portfolios to protect against risk and gain access to capital in order to finance consumer and productive purchases (Stark, 1991; Stark \& Bloom, 1985; Stark \& Taylor, 1991). Thus, the decision to migrate by household members is a family strategy to minimize risks/uncertainties. By making such decision, a household makes an investment on migration. In return, the household expects to receive remittances (Sana \& Massey, 2005) ${ }^{1}$.

1. There are three arguments to explain whether a migrant will remit or not: altruism, self-interest, and insurance and risk sharing (Agarwal \& Horowitz, 2002; Arun \& Ulku, 2011; ZaiLiang \& Ma, 2013; Ecer \& Tompkins, 2013). It is assumed that migrants are concerned about their family members back home. Thus, they send remittances for the well-being of households members who are left behind (altruism motive) (ZaiLiang \& Ma, 2013). 
It can be expected that a household will send members to destinations with high earning potentials with the expectation of receiving higher returns, here, remittances. However, the destinations with higher earning potentials are most likely hardest to be reached (Seddon et al., 1998). But when the migrants are successful to get there and get a job, the earning potentials are higher. It is known that migrant's earning is one of the important determinants of whether one remits or not and the amount of remittances sent (Arun \& Ulku, 2011). As the earning potentials of migration vary by destinations, it is expected that the remittances received by a household from migrants will also vary by migrants' destinations. Thus, it is hypothesized that:

Net of other factors, households with migrants in destinations with high earning potentials (e.g. East and South East Asia, North America, Europe and Australia or in the Middle East) will be more likely to report that they received remittances from migrants compared to those who are in destinations with low earning potentials (such as Nepal or India); and

Net of other factors, households with migrants in destinations with high earning potentials (e.g. East and South East Asia, North America, Europe and Australia or in the Middle East) will report the higher amount of remittances received from migrants than those who are in countries with low earning potentials.

\section{The setting}

\section{Methodology}

This study was conducted in the western Chitwan Valley of Nepal. Before the 1950s, the valley was primarily covered with dense forests and was infamous for malarial infestation. In 1956, His

Next, migrants may have interest to maintain family tie with the intention of returning back home. This intention will motivate them to remit. The third one is the insurance and risk sharing also termed as the contractual agreement. According to Arun \& Ulku (2011), this is basically a mutual agreement between the migrant and his/her family members that they will help each other in difficult times (risk sharing). Or, the agreement could be to pay back the cost of migration or education incurred by migrant's family. These motives may overlap. This study, however, does not intend to test these arguments. 


\section{8| Prem Bhandari}

Majesty's Government of Nepal in collaboration with the United States Government's International Cooperation Assistance program, implemented a malaria eradication campaign and distributed land parcels to people coming from adjoining districts of the country. The flat terrain with its highly fertile soil and warm climate offered promising opportunities for people who were struggling with the steep hill and mountain slopes.

Chitwan, once known as a "death valley" soon became a melting pot, receiving people from all over the country (Shrestha, 1990; Shivakoti et al., 1997). Recently, Chitwan has experienced dramatic changes in population mobility, transitioning from a frontier destination for in-migrants from surrounding hill districts of Nepal to one of the country's major migrant-sending districts (Bhandari, 2004; Bhandari \& Ghimire, 2016). According to 2011 census, as many as $29 \%$ (27\% for Nepal) of the households reported that at least one member was absent from household. About 9\% (Nepal = $7 \%$ ) population were reported to be absent of which $16 \%$ (Nepal= $13 \%)$ were males and $2 \%(\mathrm{Nepal}=2 \%)$ were females. This absentee population includes both internal and international migrants.

Farming remains the primary source of livelihood in the Chitwan Valley. The valley is inhabited mostly by in-migrants, especially from pahad, i.e., the hill and mountains and other adjacent Tarai districts including India. Chitwan's central location and relatively well-developed transportation network have been the catalytic forces for turning it into a hub for business and tourism. This has resulted in a rapid proliferation of government services, businesses, and wage labor opportunities in the district (Shivakoti et al., 1999).

\section{Data}

The data were collected in 2013 from migrant sending households. Migrant sending households come from 30 randomly selected geographic clusters also called the neighborhoods. The neighborhoods are the lowest level sampling units chosen. To select neighborhoods, first, the study area of western Chitwan Valley was divided into three different strata based on the approximate distance from Narayanghat, the urban center of the Chitwan District, to select a representative sample of neighborhoods. Stratum 1 included areas 


\section{Dhaulagiri Journal of Sociology and Anthropology Vol. 10, $2016 \mid 9$}

nearest to Narayanghat, stratum 3 included areas farthest from it and stratum 2 included areas in between. The samples were selected at two stages. In the first stage, in each stratum 10 settlements were randomly sampled based on probability proportionate to size, thus making a total of 30 settlements. These settlements were then divided into non-overlapping clusters called neighborhood or tol that consisted of 5-15 households. For the purpose of this study, 10 neighborhoods each from three strata were selected thus making a total of 30 communities $^{2}$. The detailed discussion of the design and selection procedure of the neighborhoods is described in Barber et al. (1997).

Altogether 394 households were enumerated in 30 neighborhood clusters. Of them, 187 (47 percent) households had at least one member (age 12 years and above) away from home for most of the time in the past six months. These are the working age individuals who could earn money and send remittances back home. Proportion of migrant households is consistent with the results of the Nepal Living Standard Survey (2010/11), which reported about 53 percent households in Nepal that reported at least one absentee living currently within or outside the country.

A face-to-face interview was conducted to 185 eligible households with a 99 percent response rate. Any household that has at least one member away from home most of the time in the past six months was considered eligible for the survey. Six months' time was considered to allow a migrant to earn money and send remittances back home. Any individual 18 years of age and over who could provide information about the household, remittances and remittance use was interviewed. Multiple informants from a household were allowed to respond the household survey. Study strictly followed the standard practice of ethical codes, interviewing and data collection ${ }^{3}$. Consent was read to the informants and permission was obtained

2. These neighborhoods are outside of the 151 Chitwan Valley Family Study (CVFS) neighborhoods (see Barber et al, 1997 for CVFS information).

3. Ethical consideration: Ethical approval was sought from the Institutional Review Board (IRB) of the University of Michigan prior to implementation of the survey. In addition, the author is certified with the human subjects protection "Program for Education and Evaluation in Responsible Research and Scholarship" at the University of Michigan. 


\section{0| Prem Bhandari}

prior to the survey.

The field work collected information on migration and remittances. For each migrant, place (country) of migrant's destination by month (for 12 months), occupation, whether the household received any remittances (money, goods or gifts) from the migrant during the study-year, and, if received, the amount of money or the value of goods or gifts received by the household from each person each month in the past 12 months. This information was recorded for each migrant for each month. In addition, information about each migrant's demographic characteristics such as age, gender, current place of residence, marital status, migration experience, and education were collected. For this study, out-migration is defined as any departure from the neighborhood lasting at least three months or more (most of the time in the past six months) for any reason. It includes movement within or outside of Nepal. Other information collected was household size and caste/ethnicity.

\section{Measures}

There are two outcome measures. This study utilized data from migrants who were currently working at the destination as reported by the household informant.

Outcome 1. Receipt of remittances. The first outcome measure is whether a household received remittances or not from a migrant who is working outside of Chitwan in Nepal or abroad. Information was collected by asking, "In the past 12 months, did you or your household receive money, goods or gifts from.....?' The response was recorded ' 1 ', if the household received remittance in any month in the past 12 months and otherwise ' 0 .'

Outcome 2. Amount of remittances received. The second outcome measure is the amount of remittances received by a household from each migrant. The information was collected by asking, "Altogether, how much money did you or your household receive in the past 12 months, including the value of any goods or gifts? Please also tell me when did you receive?" The amount (in Nepali Rupees) was recorded in the month when the household received the remittance. The amount was summed up for the year to calculate the total 
amount of remittance received by the household in a year. Then, the amount was divided by total number of months the migrant was away from home in the year to calculate migrant's months-adjusted remittance ${ }^{4}$. The amount of migrant's months-adjusted monthly remittance (natural $\log )^{5}$ was used as the outcome measure.

Explanatory measure and controls: Migrant's destination was used as the primary explanatory measure to examine whether remittance receipt varied by destination. Migration destinations are grouped as: (a) outside Chitwan in Nepal, (b) India, (c) Middle East, (d) Other Asia, and (e) America, Australia and Europe. These groupings are as used by Seddon et al. (1998). Those who migrated to Nepal are considered as the reference category. Individual level controls are sex of the remittance sender (male/female), age (15-24; 25-34 and 35 and above), education ( 5 years or below, 6-11 years and 12 years and above), marital status (currently married vs. others), and migration experience (number of years). Household level controls used are the number of migrant's from the same household, household size and caste/ethnicity (grouped as Brahmin/Chhetri, Dalit, Hill Janajati, Newar and Tarai Janajati).

\section{Analytical strategy}

First, descriptive statistics of each measure used in the analysis are provided. Next, multivariate models were estimated to examine the influence destination may have on remittance received by a household. Because migrant households were clustered in neighborhoods multilevel modeling (hierarchical linear modeling) techniques was used to estimate the models.

The first outcome measure, whether a household received any remittances or not from each working migrant is measured as a dichotomy: coded " 1 " if a household received remittances from the migrant and " 0 " otherwise. As migrants are clustered within

4. Some migrants were away from home for the whole year and others were away only for a couple of months. Therefore, the migrant's-months adjusted amount of remittances received by a household per month was calculated.

5. The actual amount of remittances was transformed to natural log to normalize the data. 


\section{2| Prem Bhandari}

neighborhoods, multilevel logistic regression models are estimated using SAS GLIMMIX procedure. This strategy takes into account of clustering of individuals, here individual migrants, by neighborhoods. Results are provided as odds ratios, which are anti-logs of the raw logit coefficients. These odds ratios can be interpreted as: if the coefficient is greater than 1 , the effect is positive and every unit increase in the independent variable increases the odds of receiving remittances by the household. Conversely, if the coefficient is less than 1 , then every unit increase in the independent variable decreases the odds of receiving remittances by the household.

The second outcome measure, the amount of remittances (logged) received by a household from each migrant per month is a ratio measure. Thus, a multilevel OLS regression technique was used to estimate the models.

\section{Findings}

\section{Remittance received by migrant households}

Of the total migrant households $(n=185), 75$ percent $(n=139)$ of them reported that the household received remittances from migrants in the past 12 months (Table 1). At the national level, this figure was 56 percent in 2010/11 (Central Bureau of Statistics, 2011). Of the total 283 individual migrants from 185 households, 150 (53 percent of the total) migrants remitted. Out of the total remittance recipient households, 93 percent households received remittances from one migrant and the remaining households received it from 3 or more migrants. 
Dhaulagiri Journal of Sociology and Anthropology Vol. 10, $2016 \mid 13$

Table 1: Number of migrants and remittance sending individuals by household in western Chitwan, Nepal, 2013.

No. of migrants Households with migrant Households received remittances from migrants

\begin{tabular}{lcccl} 
& Number & $\%$ & Number & $\%$ \\
\hline 1 & 124 & 67.0 & 129 & 92.8 \\
2 & 36 & 19.5 & 9 & 6.5 \\
3 plus & 25 & 13.4 & 1 & 0.7 \\
Total households & 185 & 100.0 & 139 & 100.0
\end{tabular}

Total migrants 283

On average, a household with any migrant received NRs 150,562 $(\mathrm{US} \$ 1,505)^{6}$ in a year (NRs 12,547 or US\$125 per month) (Table 2). One-half of the migrant households received NRs 100,000 (median) per year (or NRs 8,333 per month). Among remittance receiving households, a household on average received NRs 200,388 (US\$2,004) in a year (NRs 16,700 or US\$167 per month). The median for the remittance receiving households was NRs 140,000 per year (or NRs 11,667 per month). Amount of remittances received per migrant is also provided in Table 2.

6. US\$ $1=100$ Nepali Rupees (2013); US\$ $1=75$ Nepali Rupees (2010) 


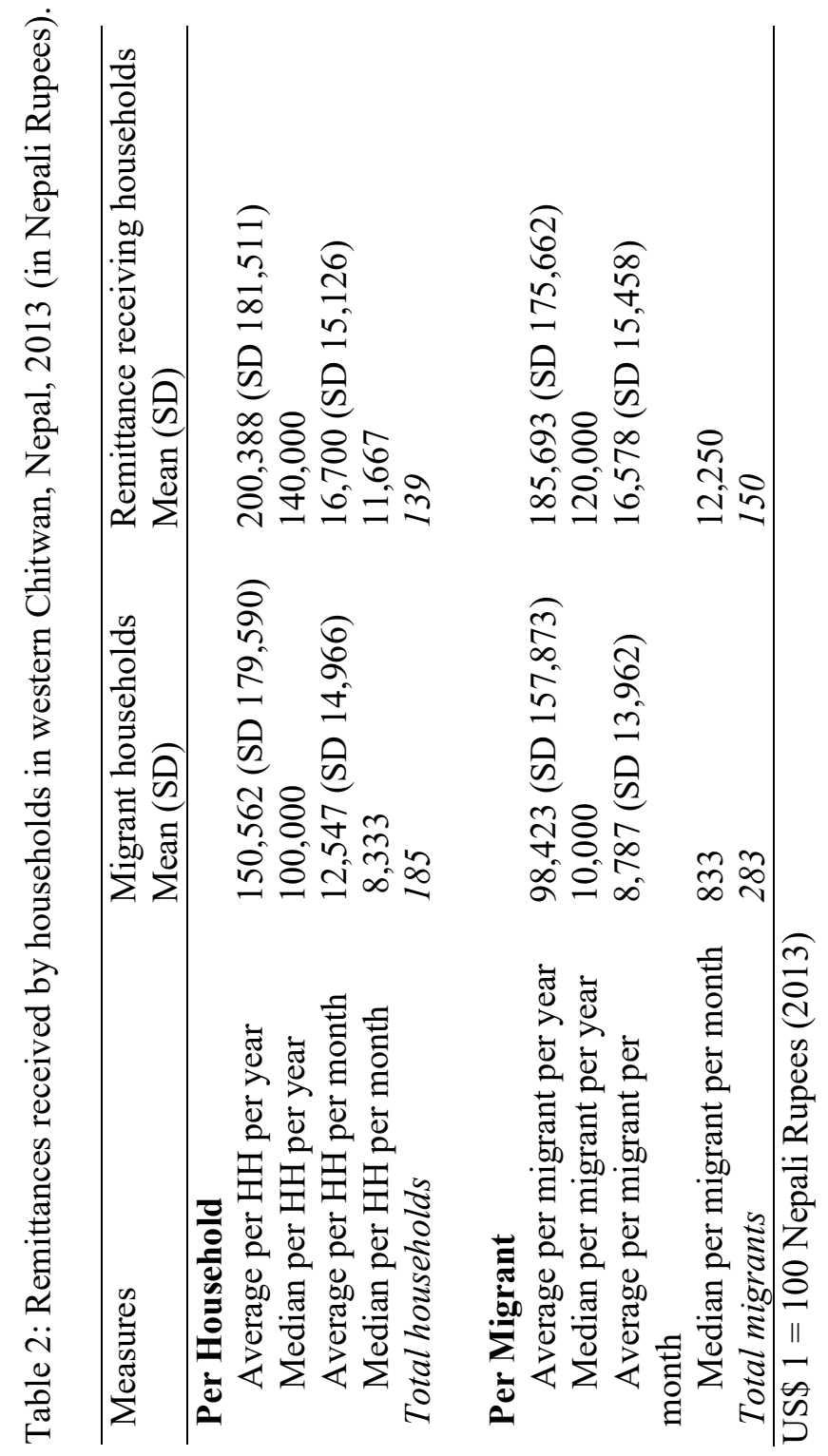




\section{Migrants by destination}

Of the total migrants ( $\mathrm{n}=283), 29$ percent were within Nepal and 71 percent were outside Nepal. Of the total, 33 percent migrants were in the Middle East, 17 percent in Other Asian countries (Malaysia, Japan, South Korea and Thailand), 12 percent in India and 10 percent in America, Australia and Europe. Even from such a small sample of households, migrants were distributed in 20 different countries outside Nepal (Table 3). Saudi Arab was the most popular international destination (12.4\%) followed by India ( $11.7 \%$ cent), Japan $(9.5 \%)$ and Qatar (8.1\%).

Table 3: Destinations of migrants from the western Chitwan, Nepal, 2013.

\begin{tabular}{lll}
\hline Destination Countries/Regions & N & Percent \\
\hline 1. Nepal & 82 & 29.0 \\
2. India & 33 & 11.7 \\
3. Middle East & 92 & 32.7 \\
Saudi Arab & 35 & 12.4 \\
Qatar & 23 & 8.1 \\
UAE & 22 & 7.8 \\
Kuwait & 6 & 2.1 \\
Bahrain & 3 & 1.1 \\
Oman & 1 & 0.4 \\
Israel & 1 & 0.4 \\
Jordan & 1 & 0.4 \\
4. Other Asia & 47 & 16.6 \\
Japan & 27 & 9.5 \\
Malaysia & 15 & 5.3 \\
South Korea & 3 & 1.1 \\
Thailand & 2 & 0.7 \\
5. America, Australia and Europe & 29 & 10.3 \\
Australia & 14 & 4.9 \\
Belgium & 4 & 1.4 \\
Canada & 2 & 0.7 \\
Germany & 1 & 0.4 \\
Poland & 1 & 0.4 \\
United Kingdom & 4 & 1.4 \\
USA & 3 & 1.1 \\
\hline Total individuals from 185 households & $\mathbf{2 8 3}$ & $\mathbf{1 0 0}$ \\
\hline & & \\
& &
\end{tabular}




\section{6| Prem Bhandari}

\section{Characteristics of working migrants}

Now, turn to research question: does remittance received by a household vary by migrant destination? To answer, only those migrants who were working at the destination irrespective of whether the household received remittances or not from them $(n=195 ; 69 \%$ of total migrants) were included in the analysis.

Descriptive statistics of the measures are provided in Table 4. Household informant(s) reported that they received remittances from 74.4 percent of the migrants who were working in various destinations. Altogether, significantly large proportions $(45 \%)$ of the currently working migrants were located in the Middle East, followed by Other Asia (19\%), Nepal (15\%), India (11\%) and America, Australia and Europe (10\%). About 13 percent of these migrants were females, nearly one-half $(46 \%)$ of them were between the ages of 25-34 years and four-fifths of them were currently married. Slightly over one-half of the migrants had 6-11 years of education, and a migrant's average length of time at the destination was slightly over 4 years.

A migrant household had, on average, about 2 migrants who were working at the destination. The size of the household was about 6 . About one-half of the migrants belonged to Brahmin/Chhetri, 16 percent each of Dalit and Hill Janajati, 13 percent Tarai Janajati and about 8 percent were Newar. Table 4 also presents the distribution of remitters and non-remitters. 


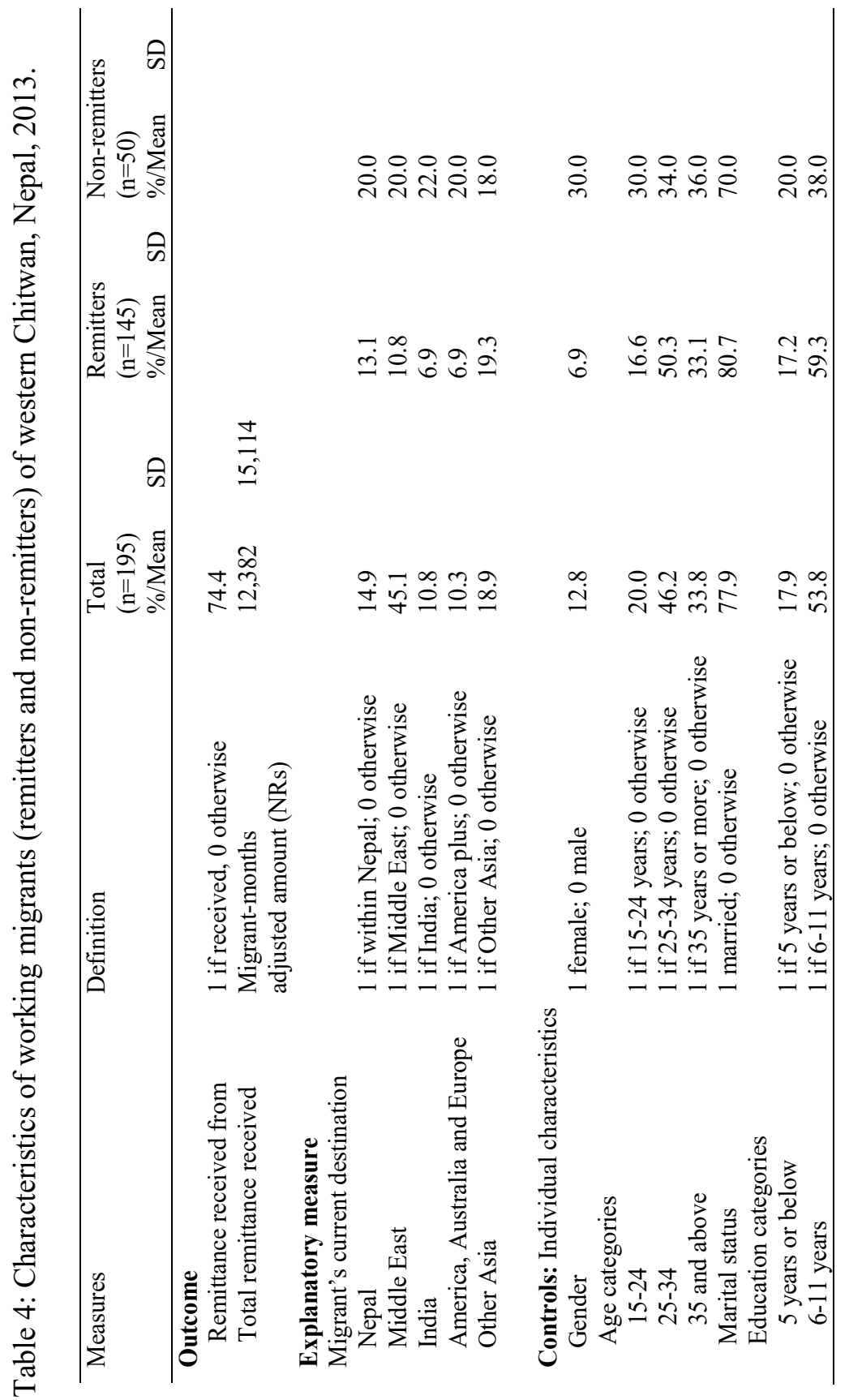




\section{8| Prem Bhandari}

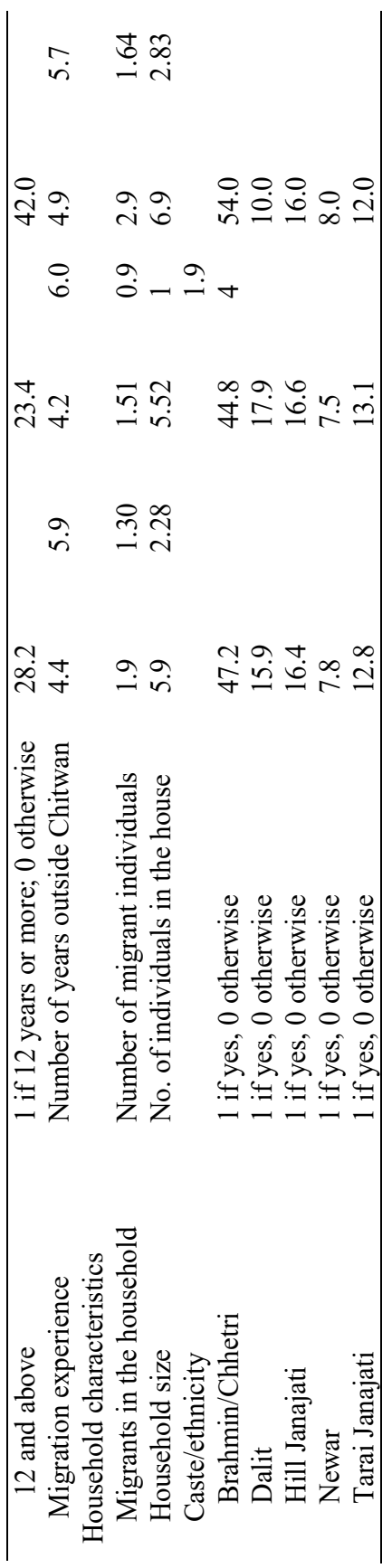




\section{Remittance received by households from working migrants}

Table 5 shows that there is a variation in proportion of household report of remittances received by migrant's destination. Results in column 1 show that households who had working migrants in Nepal received remittance from 65.5 percent of them. Households received remittances from 89 percent of the migrants who were working in the Middle East followed by those who were in America, Australia and Europe (75.7\%). Households received remittances from fewer migrants who were working in Other Asian countries (50\%) and India $(47.7 \%)$.

Table 5: Remittances received by households from working migrants by destination, 2013.

\begin{tabular}{|c|c|c|c|}
\hline $\begin{array}{l}\text { Migrant } \\
\text { destinations }\end{array}$ & $\begin{array}{l}\text { Column } 1 \\
\text { Remittance } \\
\text { received } \\
(\%)\end{array}$ & $\begin{array}{l}\text { Column } 2 \\
\text { Remittance } \\
\text { received } \\
\text { from all } \\
\text { working migrants } \\
\text { Mean (SD) (NRs) }\end{array}$ & $\begin{array}{l}\frac{\text { Column } 3}{\text { Remittance }} \\
\text { received } \\
\text { from remitters } \\
\text { only } \\
\text { Mean (SD) } \\
(\mathrm{NRs})\end{array}$ \\
\hline Nepal & 65.5 & $2,583(3,673)$ & $3,942(3,915)$ \\
\hline India & 47.7 & $5,133(9,393)$ & $10,779(11,333)$ \\
\hline Middle East & 88.6 & $15,040(14,965)$ & $16,969(14,833)$ \\
\hline Other Asia & 50.0 & $11,031(15,809)$ & $22,062(16,037)$ \\
\hline $\begin{array}{l}\text { America, } \\
\text { Australia } \\
\text { and Europe }\end{array}$ & 75.7 & $18,584(18,235)$ & $24,558(17,065)$ \\
\hline No. of migrants & 195 & 195 & 145 \\
\hline
\end{tabular}

US\$ $1=100$ Nepali Rupees (2013)

Now the question is: do the results in Table 5 hold true even after adjusting for other factors? Below, the results of multilevel multivariate analysis (Table 6) are discussed.

First, a null or unconditional model was estimated. The results of unconditional model provide just the random effects for the intercept and do not include the effects of any predictors (results are not shown). Results from the null model estimated level-1 intercept of the outcome measure whether a household received remittances from a migrant or not as a random effect of level-2 geographic 


\section{0| Prem Bhandari}

clusters also called neighborhoods with no other predictors at level-1 or level-2. The intercept is the level-2 random intercept representing the log odds of receiving remittance or not by a household in a typical cluster. The random intercept $(1.412 ; \mathrm{p}<.001$; result not shown) is statistically significant which implied that there is a variation in receiving remittances by a household by geographic clusters suggesting for a multilevel modeling as a better approach of analysis (Garson, 2007).

Next, two random coefficient models were estimated. Results in model 1 are the fixed effects of level-1 predictors, migrant's current place of destinations (these results are similar to those in Table 5, column 1). Results show that households were significantly more likely to receive remittances from migrants who were working in the Middle East and Other Asian countries as compared to the remittance/income of those who are working in Nepal. To be precise, the odds of receiving remittances from a migrant who is working in the Middle East is 4.73 times greater (odds ratio=4.73; $\mathrm{p}<=.01$; model 1) than the odds of receiving remittances/ income from migrants working in Nepal. Similarly, the odds of receiving remittances from a migrant who is in Other Asian countries is 3.50 times higher (odds ratio $=3.50 ; p<.10$ ) than the odds of receiving remittances/income from migrants in Nepal. The unadjusted results show that households are less likely to report receiving remittances from migrants who are working in India and America, Australia and Europe, but the results are not statistically significant.

Results in model 2 are the effects of migrant's destination on whether a household received remittance or not controlling for sex, age, marital status, education, migration experience, number of migrants in the household, and household size and caste/ethnicity. Net of other controls, the results show that households were significantly less likely $(92 \%)$ to receive remittances from migrants who were working in India (odds ratio $=0.08 ; \mathrm{p}<=.05$; model 2 ) compared to the remittance received from those who were working in Nepal. This could be mainly because there are no other methods of sending remittances back home other than by hand carriage (Thieme and Wyss, 2005). Results for the Middle East and Other Asian countries turned out to be statistically not significant after controlling for other characteristics particularly after the inclusion of age and education suggesting that these factors were more important than destination itself. 
Table 6: Estimated receipt of remittances (odds ratios!) by households in western Chitwan, Nepal, 2013 (n=195).

\begin{tabular}{|c|c|c|}
\hline Measures & Model 1 & Model 2 \\
\hline \multicolumn{3}{|l|}{ Current destination $(\mathrm{Ref}=\mathrm{Nepal})$} \\
\hline India & 0.32 & $0.08 *$ \\
\hline Middle East & $4.73 * *$ & 2.55 \\
\hline Other Asia & $3.50+$ & 3.84 \\
\hline America, Australia and Europe & 0.56 & 0.33 \\
\hline \multicolumn{3}{|l|}{ Individual characteristics } \\
\hline Gender $(1=$ female $)$ & & $0.15 * *$ \\
\hline \multicolumn{3}{|l|}{ Age categories $(\operatorname{Ref}=15-24)$} \\
\hline $25-34$ & & 3.61 \\
\hline 35 and above & & 2.11 \\
\hline Marital status ( $1=$ married $)$ & & 1.14 \\
\hline \multicolumn{3}{|l|}{ Education (Ref $=5$ years or below) } \\
\hline 6-11 years & & 1.71 \\
\hline 12 and above & & 1.47 \\
\hline Migration experience (years) & & $1.09+$ \\
\hline \multicolumn{3}{|l|}{ Household characteristics } \\
\hline Number of migrants from the household & & $0.34 * *$ \\
\hline Household size & & 1.04 \\
\hline \multicolumn{3}{|l|}{ Caste/ethnicity (Ref=Brahmin/Chhetri) } \\
\hline Dalit & & 1.97 \\
\hline Hill Janajati & & 0.51 \\
\hline Newar & & 0.16 \\
\hline Tarai Janajati & & 0.58 \\
\hline Intercept & $2.50+$ & 8.81 \\
\hline$-2 \log L$ (deviance) $($ Null=213.48)\# & 188.68 & 138.31 \\
\hline AIC (Null=217.48)\# & 200.68 & 176.31 \\
\hline BIC (Null=220.22)\# & 208.89 & 202.29 \\
\hline \multicolumn{3}{|c|}{$\begin{array}{l}P<.10, * P<.05, * * P<.01, * * * P<.001 \text { all probabilities are } \\
\text { he-tailed, t-values in parenthesis } \\
\text { Smaller values compared to the null model values are } \\
\text { onsidered better. } \\
\text { Multilevel logistic regression models }\end{array}$} \\
\hline
\end{tabular}




\section{2| Prem Bhandari}

The odds of receiving remittances from a female migrant were 85 percent (odds ratio $=0.15 ; \mathrm{p}<=.01$; model 2 ) less than the odds of receiving remittances from male migrants. Migrant's age, marital status, education and migration experience were not statistically significant in determining household receipt of remittances, net of other factors. Increased number of migrants from a household reduced the odds of receiving remittances at home.

\section{Amount of remittances received by households from working migrants}

On average, a migrant household received 12,382 NRs. in a month from a migrant who was working, individually. The unadjusted (descriptive) results in Table 5 show that there is a statistically significant variation in the amount of remittances received by households from working migrants (as well as remitters) by place of destination. The unadjusted results show that on average, a household received the highest amount (NRs. 18,584, column 2) of remittance per month from migrants who were working in America, Australia and Europe. This was followed by Middle East (NRs. 15,040), Other Asian countries (NRs. 11,031), and India (NRs. 5,133). A household received a least amount (NRs. 2,583) of remittances from migrants who were working within Nepal outside of Chitwan. Among remitters only, on average, a household received NRs. 24,558 (Table 5, column 3 ) per month from migrants who were working in America, Australia and Europe. This was followed by Other Asian countries (NRs. 22,062), Middle East (NRs. 16,969), India (NRs. 10,779). Among remitters only, a household received NRs. 3,942 from migrants who were working in Nepal.

Does this variation in the amount of remittances received by households from migrants working in various destinations hold true after adjusting forother individual and household level characteristics? The results of multilevel models (Table 7) are discussed below. Two separate models are estimated. Results in model 1include migrants who are currently working at the destination irrespective of whether a household received any remittance from them or not. In model 2, only those migrants who are currently working at the destination 


\section{Dhaulagiri Journal of Sociology and Anthropology Vol. 10, $2016 \mid 23$}

and the household reported receipt of remittances from him/her are examined.

First, as discussed earlier, a null or unconditional model was estimated. The random intercepts in both models are statistically significant which implied that there is a variation in the amount of remittances received by a household by geographic clusters suggesting for a multilevel modeling (Garson, 2007). Outcome measure, the amount of remittances received per month, is normalized (natural log) to avoid influence of any outliers in the data.

The results in model 1, among all working migrants, show that the amount of remittances received from migrants statistically significantly varied by destination even after adjusting for all other controls. For instance, household report of the amount of remittances received from migrants who were working in India, in fact, was significantly less (slope $=-2.43$ (logged), $\mathrm{p}<.05$, model 1) compared to those who were working in Nepal. Surprisingly, this difference was wiped out (slope $=0.48$ (logged), $\mathrm{p}>.05$, model 2 ) when only remittance sending individuals were included in the model (model 2 ). This result suggests that if only migrants who send remittances are compared, the amount of money received from migrants working in India and Nepal is not significantly different. This could be true because mostly unskilled migrants work in India. However, a household received significantly large amount of remittances from migrants who were working in Other Asian countries (2.97 times logged) and Middle East (2.10 times logged) as compared to those who were working in Nepal. Interestingly, the amount was statistically significantly not different among migrants working in America, Australia and Europe and in Nepal. When only remitters are considered (model 2), a household received significantly large amount of remittances from migrants who were working in Other Asian countries (2.97 times logged), America, Australia and Europe (2.27 times logged) and Middle East (2.10 times logged) as compared to those who were working in Nepal. These results imply that the remittance received by households does vary by migrant's destination. 
हี

章

$\frac{\sqrt{0}}{\frac{0}{0}}$

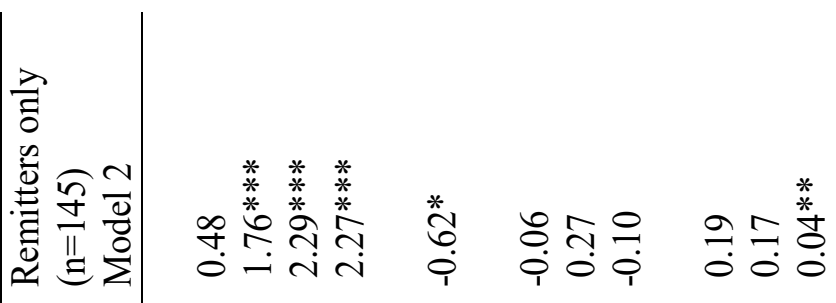

䒭

.50

五

틍

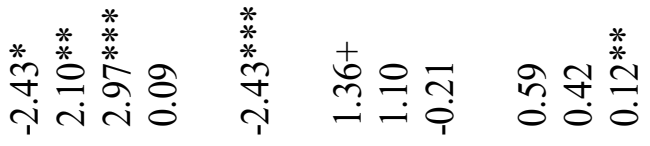

:

ల్

릉

4 잉

$\mathscr{0}$

喤

言

चु

है

छ

恶

$\therefore$ 잉

는

की
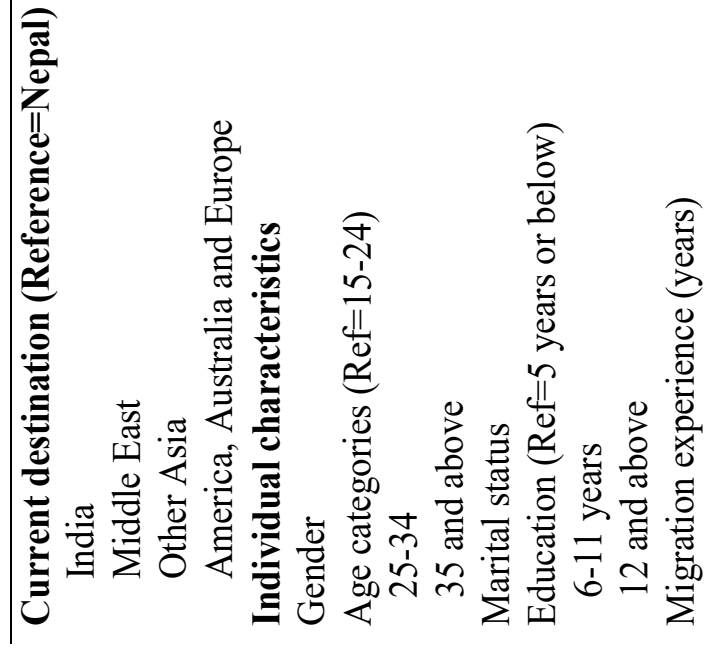


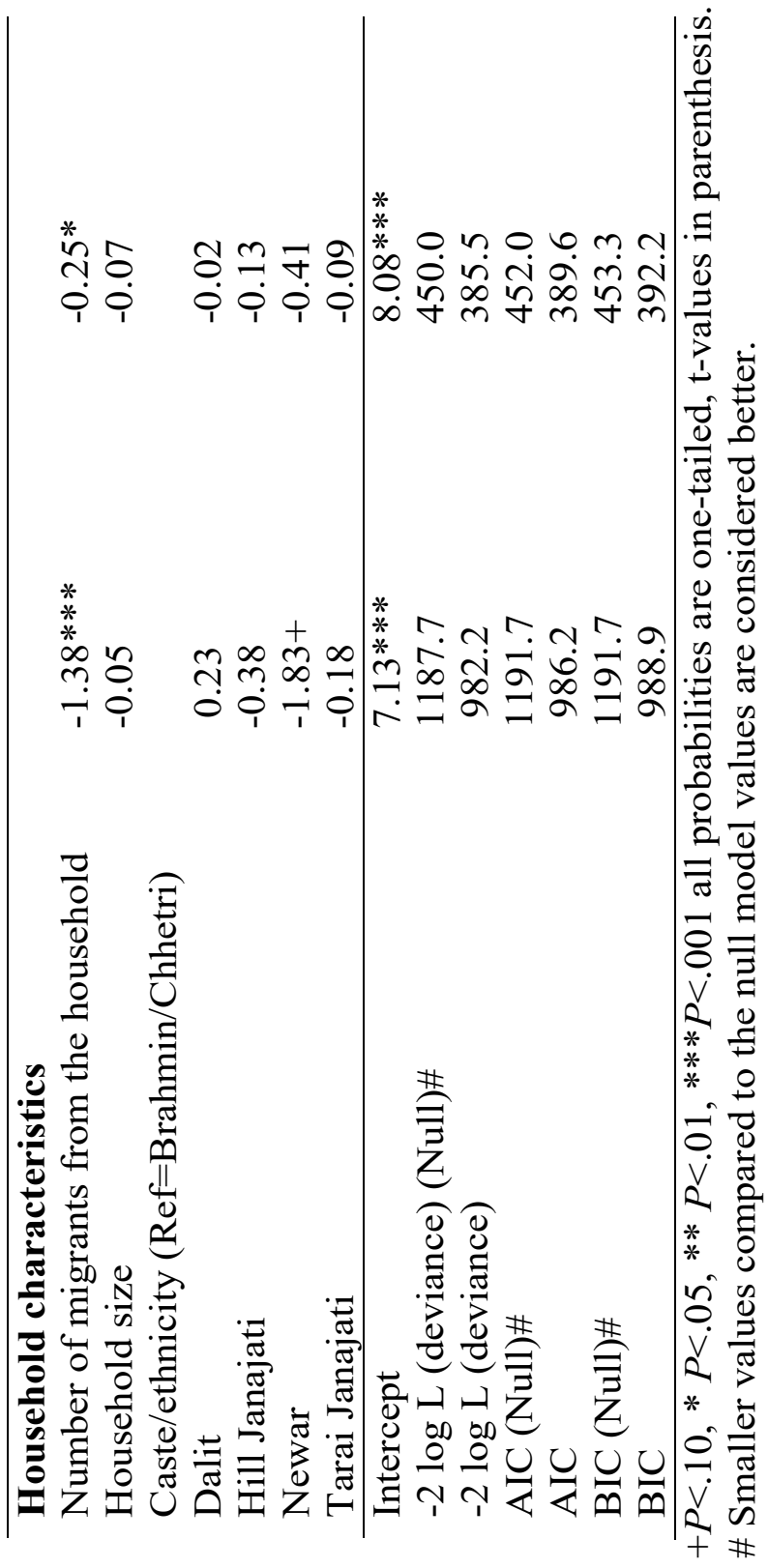




\section{6| Prem Bhandari}

A household received significantly less amount of remittances from females compared to their male counterparts (in both models 1 and 2). Migration experience slightly increased the amount of remittances received. An increase in number of migrants in the household significantly decreased the amount of remittances received by a household. This is as expected. Migrants tend to share the responsibility/obligation as well as risk and therefore are less likely to remit if a household has multiple migrants (ZaiLiang \& Ma, 2013). The amount of remittances received by households, however, did not significantly vary by migrant's age, marital status, education, household size and caste/ethnicity. These results are consistent with those of Williams et al. (2012).

\section{Discussion and Conclusion}

Nepal is experiencing massive out-migration of youths more recently. Migration has been a rite of passage for individuals. Households are increasingly relying on migration and remittances for livelihood. With the increase of out-migrants, the volume of remittances is increasing over time. Now, the remittance from migrants has been an important source of a household's economy (Nepal Rastra Bank, 2016).

Nepali youths are scattered globally. Evidence suggests that earning potentials for migrants vary by destination. Some destinations such as America, Australia, Europe, Japan, and South Korea have high earning potentials. Middle Eastern countries are of medium earning potentials. Other destination such as India has low earning potential. It was widely believed that the remittance received by households does vary by migrant's destination. However, less was known about this and empirical support was scanty. This exploratory study provides empirical evidence on whether the receipt of remittances and the amount of remittances received by households do vary by migrant's destination using the recently collected data from the western Chitwan Valley of Nepal.

Findings reveal that net of migrant's and household characteristics, a household receipt of remittances varied by migrant's destination. Adjusting for other factors, if migrants are working in India, a 
household is significantly less likely to receive remittances from them as compared to those who are working in Nepal. This could be because most migrants may bring remittances with them when they return. Evidence also suggests that a household is more likely to receive remittances, if a member is working in the Middle East or in Other Asian countries. Surprisingly, if a member is working in America, Australia or Europe, a household is equally likely to receive remittances from those who are working in Nepal. This could be due to the fact that most migrants at these destinations are usually with their families and may not be able to send savings back home. Or, because of the possibility of settlement, migrants may also spend earnings in order for settlement at the destination.

The evidence further suggests that the amount of remittances received by households from migrants working in India is not statistically significantly different from the amount received from those working in Nepal. This is as expected because India is the country with low earning potential. Nepali migrants are compelled to go to India due to several reasons. It is easy and less expensive to go to India and find a job (Seddon et al., 1998). Even the unacceptable jobs (with less respect and low earning or so called faltukam or useless work) in Nepal are acceptable in India (Sharma, 2011). Temporary migration of short duration is another reason to migrate to India. Migrants may go to India during off-crop seasons in Nepal, work there for a short period of time (3-4 months) and return home with some money which is not possible in other destinations. Migrants escape from traditional work particularly halo jotne (ploughing the field) or bharibokne (carrying loads) when they go to India.

As hypothesized, evidence show that households received significantly more amount of remittances from migrants working in regions with high earning potentials. For instance, households received significantly higher amount of remittances from those who were working in Other Asian countries (2.29 times logged), America, Australia and Europe (2.27 times logged) and the Middle East (1.76 times logged) as compared to the amount received from migrants working in Nepal, net of all other factors. The largest (adjusted) amount of remittances was received from migrants working in Other Asian countries (e.g. Japan, South Korea, Malaysia) followed by 


\section{8| Prem Bhandari}

America, Australia and Europe and the Middle East. These adjusted results are as expected by Seddon et al. (1998).

The results from this study have important implications. First, there is variation in the amount of remittances received from migrants working in various destinations. As hypothesized, the evidence suggests that households received significantly higher amount of remittances from migrants who are working in countries with high earning potentials and vice versa. Such destination specific variation in the amount of remittance received by households will increase income inequality among migrant households. Moreover, organizing migration in countries with high earning potentials requires high investment and social networks in terms of education, training, and finances for travel (Sharma, 2011; Seddon et al., 1998). Thus, only resourceful individuals may migrate to countries with higher earning potentials. Using data from Nepal Living Standard Survey (2003/04), Gurung (2012) found that socially included groups (privileged caste, rich, educated, land owners) were more likely to choose destinations where earning opportunities are relatively better. Gurung reported that individuals from richer households were found to migrate to countries other than India and those from poorer households migrated to India or rural Nepal. On the other hand, Hill Janajati migrants were more likely to go to the Middle East, Malaysia and other developed countries. This scenario suggests individuals from households that are already privileged in Nepal will move to destinations with high earning potentials. Such households receive higher amount of remittances, thus further deepening the inequalities among households in sending areas. Similar observations were made by Jones and Basnett (2013) who reported that nearly one-third of the remittance was received by the richest quintile households.

Moreover, evidences suggest that remittance has important effect on household's poverty reduction and children's human capital development such as schooling and health (e.g. De \& Ratha, 2012; Dey, 2015). Variation in the amount of remittances received by migrant households from migrants working in different destinations will have important implications on the utilization of remittances by households. Such a variation in the amount of remittances received by households will have differential impact on poverty alleviation 
and children's human capital development. Again the privileged households will be in better-off situation. This is just one example. There could be several important implications where remittances could have direct or indirect effects. This will lead to a vicious cycle that originates from destination specific migration. Further studies are needed to examine such influences.

While this study has important contributions to the field of migration and remittance research, it is not free from limitations. The results are based on data from a small sample of migrant households collected from a part of the southern Tarai plain of rural Nepal. Thus, the findings may not be generalizable to other parts of the country. Moreover, the associations described earlier are based on cross-sectional data. Thus, the conclusions should be considered rather cautiously. However, this study helps generate theoretically important and policy relevant research questions for future studies. It is also believed that this study will help develop hypothesis and test the causality of the effects of destination specific migration and remittances on various aspects of household economy. The findings will be useful to those who are interested in studying the long-term consequences of migration and remittances such as reducing income inequality or poverty.

\section{References}

Acharya, C. P. \& Leon-Gonzalez, R. (2014). How do migration and remittances affect human capital investment? The effects of relaxing information and liquidity constraints. The Journal of Development Studies, 50(3), 444-460, http://dx.doi.org/1 $0.1080 / 00220388.2013 .866224$.

Acosta, P. ,Calderon, C., Fajnzylber, P. \& Lopez, H. (2006). Remittances and development in Latin America.World Development,29 (7), 957-987. http://dx.doi.org/10.1111/ j.1467-9701.2006.00831.x

Adams, R. H., Jr. (2011). Evaluating the economic impact of international remittances on developing countries using household surveys: A literature review.Journal of Development Studies,47(6), 809-828. http://dx.doi.org/10.1 080/00220388.2011.563299 


\section{0| Prem Bhandari}

Adhikari, J. (2001). Mobility and agrarian change in central Nepal. Contributions to Nepalese Studies. The Free Library, http:// www.thefreelibrary.com/Mobility and agrarian change in central Nepal (1).-a092840368.

Agarwal, R. \& Horowitz, A. W. (2002). Are international remittances altruism or insurance? Evidence from Guyana using multiplemigrant households.World Development, 30 (11), 20332044. http://dx.doi.org/10.1016/S0305-750X(02)00118-3

Arun, T. \& Ulku, H.(2011). Determinants of remittances: The case of the South Asian community in Manchester. Journal of Development Studies, 47 (6), 894-912. http://dx.doi.org/10 $.1080 / 00220388.2010 .527951$

Barber, J. S., Shivakoti,G. P., Axinn, W. G. \& Gajurel, K. (1997). Sampling strategies for rural settings: A detailed example from the Chitwan Valley Family Study, Nepal.

Nepal Population Journal, 6 (5),193-203.

Bhandari, P. B. (2004). Relative deprivation and migration in an agricultural setting of Nepal.Population and Environment, 25(5), 475-499. http://dx.doi.org/10.1023/ B:POEN.0000036931.73465.79

Bhandari, Prem B. \& Ghimire, D. J. (2016). Rural agricultural change and individual out-migration.Rural Sociology, DOI: 10.1111/ruso. 12106.

Bhandari, P. \& Chaudhary, I.(2016). A calendar method of collecting remittance use data in a remittance dependent setting of Nepal. Migration and Development, http://dx.doi.org/10.10 80/21632324.2015.1129689.

Bohra-Mishra, P. \& Massey, D. S. (2009).Processes of internal and international migration from Chitwan, Nepal. International Migration Review, 43(3), 621-651.

Bohra-Mishra, P. \& Massey, D. S. (2011). Individual decisions to migrate during civil conflict. Demography, 48(2), 401-424.

Bohra-Mishra, P.(2013). Labour migration and investments by remaining households in rural Nepal. Journal of Population Research, 30(2),171-192. http://dx.doi.org/10.1007/s12546012-9097-2

Brown, R. P. C. \& Ahlburg, D. (1999). Remittances in the South Pacific.International Journal of Social Economics, 26, 325- 
344. http://dx.doi.org/10.1108/03068299910229721

Central Bureau of Statistics (2011). Nepal Living Standards Survey 2010/11: Statistical Report Volume Two. Central Bureau of Statistics. National Planning Commission Secretariat, Government of Nepal. Kathmandu.

Central Bureau of Statistics (2012).Population Census 2011 Preliminary Report.Government of Nepal.Kathmandu.

Conway, D. \& Cohen, J. H. (1998).Consequences of migration and remittances for Mexican transnational communities. Economic Geography, 74(1), 26-44.

De, P. K. \& Ratha, D. (2012). Impact of remittances on household income, asset and human capital: Evidence from Sri Lanka. Migration and Development.1(1), 163-179.

Dey, S. (2015). Impact of remittances on poverty at origin: A study on rural households in India using covariate balancing propensity score matching. Migration and Development, 4(2), 185-199.

Ecer, S. \& Tompkins, A. (2013).An econometric analysis of the remittance determinants among Ghanaians and Nigerians in The United States, United Kingdom, and Germany. International Migration, 51(Supplement s1) e53-e69.

Garson, G. D.(2013). Fundamentals of hierarchical linear and multilevel modeling.Hierarchical linear modeling: Guide and applications by Garson. Los Angeles, London, New Delhi, Singapore, Washington DC: Sage Publications Inc, pp. 3-26.

Government of Nepal (2014). Labour migration for employment: A status report for Nepal: 2013/2014. Government of Nepal. Kathmandu, Nepal: Ministry of Labour and Employment, Department of Foreign Employment.

Government of Nepal 2071 (2014).National Population Policy 2071. Government of Nepal. Kathmandu, Nepal: Ministry of Health and Population, .

Gurung, H. B. 1983. Internal and International Migration in Nepal. Kathmandu, Nepal: HMG Population Commission

Gurung, H. B. (1998). Nepal social demography and expressions. Kathmandu: New Era. 
Gurung,Y. B.(2012). Migration from Rural Nepal:ASocial Exclusion Framework. Himalaya, the Journal of the Association for Nepal and Himalayan Studies. 31 (1): Article No. 12

Graner, E.\& Gurung, G. (2003). Arab kolahure: Looking at Nepali labour migrants to Arabian countries. Contributions to Nepalese Studies, 30(2), 295-325.

Hoermann, B. \& Kollmair, M. (2009).Labor migration and remittances in the Hindu Kush-Himalayan region.ICIMOD Working Paper. Kathmandu, Nepal.

Jones, H. \& Basnet, Y. (2013). Foreign Employment and Inclusive Growth in Nepal. What can be done to improve impacts for the people and the country? London: Overseas Development Institute.

Kern, Alice and Ulrike Muller-Boker. (2015). "The Middle Space of Migration: A Case Study on Brokerage and Recruitment Agencies in Nepal. Geoforum, 65:158-169.

Kollmair, M., Manandhar,S.,Subedi, B. \&Thieme, S. (2006). New figures for old stories: Migration and remittances in Nepal. Migration Letters, 3(2),151-160.

Lokshin, M., Bontch-Osmolovski, M. \& Glinskaya, E. (2007). Work-related migration and poverty reduction in Nepal. World Bank Policy Research Working Paper 4231, May, Washington, D.C.

Massey, D. L. \& Basem, L. C. (1992). Determinants of savings, remittances, and spending patterns among U.S. migrants in four Mexican communities.Sociological Inquiry, 62(2), 185-207.

Massey, D. S., Williams, N. E.,Axinn, W. G. \& Ghimire, D. J.(2010). Community services and out-migration. International Migration, 48 (3), 1-41.

Massey, D. S., Axinn, W. G. \& Ghimire, D. J.(2010). Environmental change and out-migration: Evidence from Nepal. Population and Environment, 32(2),109-136.

Migration and Development Brief (2015). Online Websitehttps://siteresource.worldbank.org/ INTPROSPECTS/Resources/334934-1288990760745/ MigrationandDevelopmentBrief24.pdf. 
Ministry of Health and Population (MOHP) [Nepal], New ERA, \& ICF International Inc. (2012). Nepal Demographic and Health Survey 2011. Kathmandu, Nepal: Ministry of Health and Population, New ERA, and ICF International, Calverton, Maryland.

Nepal, R. (2012). Remittances and livelihood strategies: A case study in eastern Nepal. Knerr, B. (Ed.) International Labor Migration, Vol 14. Germany: Kassel University Press.

Nepal Rastra Bank. (2016). Fifth Household Budget Survey 2014/14. Nepal Rastra Bank. Kathmandu, Nepal.

Ngoma,A. L., \& Ismail, N. W. (2013).Do migrant remittances promote human capital formation? Migration and Development, 2 (1), 106-116.

Ozaki, M. (2012). Worker Migration and Remittances in South Asia. South Asia Working Paper Series. No. 12, May 2012. Asian Development Bank, Philippines. (Retrieved on September 17, 2015,http://adb.org/sites/default/files/pub/2012/workermigration-remittances-south-asia.pdf).

Pant, B. (2008). Mobilizing remittances for productive use: A policyoriented approach. NRB Working Paper. Nepal Rastra Bank, Research Department, Serial Number: NRB/WP/4. December 2008.

Pattisson, P. (2014, December 15). For aspiring Nepali migrants, the risks start at home. Aljazeera America. Retrieved from website http://america.aljazeera.com/articles/2014/12/15/ for-aspiring-nepalimigrantstherisksstartathome.html.

Piotrowski, M., Ghimire, D. J. \& Rindfuss, R. (2013). Farming systems and rural out-migration in Nang Rong, Thailand, and Chitwan Valley, Nepal. Rural Sociology, 78 (1), 75-108.

Piotrowski, M. (2013). Mass media and rural out-migration in the context of social change: Evidence from rural Nepal. International Migration, 51(3),169-193.

Piotrowski, M., and Tong, Y. (2010). Economic and non-economic determinants of return migration: Evidence from rural Thailand. Population, English edition, 65 (2), 333-348.

Rathaur, K. R. S. (2001). "British Gurkha Recruitment: A Historical Perspective." Voice of History 16(2):19-24 
Rozelle, S., Taylor, J. E. \& de Brauw, A. (1999). Migration, remittances, and agricultural productivity in China.American Economic Review, 89 (2), 287-91.

Sana, M. \& Douglas S. M. (2005). Household composition, family migration and community context: Migrant remittances in four countries. Social Science Quarterly 86(2): 509-528.

Seddon, D. (2004). South Asian remittances: Implications for development. Contemporary South Asia, 13 (4), 403-420.

Seddon, D., Adkhikari, J. \& Gurung, G. (2002).Foreign labor migration and the remittance economy of Nepal. Critical Asian Studies, 34(1), 19-40.

Seddon, D., Gurung, G. \& Adhikari, J. (1998). Foreign labour migration and the remittance economy of Nepal. Himalaya, the Journal of the Association for Nepal and Himalayan Studies, 18 (2), 3-10.

Sharma, J. (2011). Culture of Migration in the Middle Hills in Nepal. In Labor Migration: Opportunities and Challenges for Mountain Livelihoods. (Vol. 59, pp. 18-20).(Sustainable Mountain Development).International Centre for Integrated Mountain Development (ICIMOD).

Sharma, J. \& Gurung, G. (2009). Impact of global economic slowdown on remittance inflows and poverty reduction in Nepal. Kathmandu, Nepal: Institute for Integrated Development Studies (IIDS).

Shivakoti, G. P., Axinn, W. G., Bhandari, P. B. \& Chhetri, N. (1999). The impact of community context on land use in an agricultural society. Population and Environment, 20 (3), 191-213.

Shrestha, N. R. (1990). Landlessness and migration in Nepal. Boulder, San Francisco, Oxford: Westview Press.

Shrestha, S. S. \& Bhandari, P.(2007).Environmental security and labor migration in Nepal. Population and Environment, 29 (1), 25-38.

Stark, O \& Taylor, J. E. (1991). Migration Incentives, Migration Types: The Role of Relative Deprivation. The Economic Journal 101(408):1163-78.

Stark, O. \& Bloom, D. E. (1985). The new economics of labor 


\section{Dhaulagiri Journal of Sociology and Anthropology Vol. 10, $2016 \mid 35$}

migration. American Economic Review, 75 (2), 173-178.

Stark, O. D. \& Levhari, D. (1982). On migration and risk in LDCs. Economic Development and Cultural Change, 31(1), 191196.

Stark, O.\& Lucas, R. E. (1988).Migration, remittances, and the family. Economic Development and Cultural Change, 36 (3), 465-81.

Stark, O.,Taylor, J. E. \& Yitzhaki, S. (1988). Migration, remittances and inequality: A sensitivity analysis using the extended Gini index. Journal of Development Economics, 28, 309-322.

Stark, O. (1978). Economic-demographic interactions in agricultural development: The case of rural-to-urban migration. Rome: Food and Agriculture Organization of the United Nations.

Stark, O. (1991). The migration of labor. Oxford: Basil Blackwell.

Taylor, J. E. \& Martin, P. L. (2001). Human capital: Migration and rural population change. In Bruce Gardner and Gordan Rausser (Eds.), Handbook of Agricultural Economics. New York: Elsevier Science.

Taylor, J. E. \& Yunez-Naude, A. (1999). Education, migration and productivity: An analytic approach and evidence from rural Mexico. Paris, France: Development Centre of the OECD.

Taylor, J. E. (1999). The new economics of labour migration and the role of remittances in the migration process. International Migration, 37(1), 63-88. http://dx.doi.org/10.1111/14682435.00066

Taylor, J. E., Arango, J., Hugo, G., Kouaouci, A., Massey, D. S. \& Pellegrino, A. (1996).International migration and community development. Population Index, 62 (2), 181212. http://dx.doi.org/10.2307/3646297

Thieme, S. \& Wyss, S. (2005). Migration patterns and remittance transfer in Nepal: A case study of SainikBasti in Western Nepal. International Migration, 43 (5), 59-98. http://dx.doi. org/10.1111/j.1468-2435.2005.00342.x

United Nations Population Facts (2015, December). Trends in international migration, 2015. Retrieved from websitehttp://www.un.org/en/development/desa/ population/migration/publications/populationfacts/docs/ 
MigrationPopFacts20154.pdf

Williams, N.E. (2009). Education, gender, andmigration in the context of social change. Social Science Research, 38 (4), 883-896. http://dx.doi.org/10.1016/j.ssresearch.2009.04.005

Williams, N. E., Thornton, A., Ghimire, D. J., Young-DeMarco, L., \& Moaddel, M. (2012). Nepali migrants to the Gulf Cooperation Council countries: Behaviors, plans, and values. In Kamrava, Mehran \& Babar, Zahra (Eds.), Migrant Labor in the Persian Gulf (pp. 155-85). London: Hurst \& Co.

Williams, N. E. (2013). How community organizations moderate the effect of armed conflict on migration in Nepal. Population Studies, 67 (3), 353-369. http://dx.doi.org/10.1080/0032472 8.2012 .754927

World Bank. (2009). Impact of Global Financial Crisis on South Asia. Washington: World Bank.

World Bank. (2011). Migration and development brief 17. Migration and Remittances Unit, Washington, DC: The World Bank.

World Bank.(2016). Migration and remittances factbook 2016. Third Edition. Washington, DC: The World Bank. Retrieved from website. http://siteresources.worldbank.org/ INTPROSPECTS/

ZaiLiang, J. L. \& Ma, Z. (2013).Migration and remittances. Asian Population Studies, 9 (2), 124-141. http://dx.doi.org/10.108 0/17441730.2013.785721

Bhandari, Prem $\mathrm{PhD}$, is a Social Demographer. He has earned $\mathrm{PhD}$ in Rural Sociology and Demography from the Pennsylvania State University, Pennsylvania. Bhandari is currently working at the Population Studies Center at the University of Michigan. His research focuses on the socioeconomic and cultural determinants of human fertility, migration and remittances, and population health in developing countries. Other areas include rural social change, population and environment relationships, and social research methods. He has published several papers in peer-reviewed journals. $\mathrm{He}$ is also an occasional reviewer of a dozen of international peerreviewed journals.

Email: prembh@umich.edu 